\title{
Pelatihan Kewirausahaan Kreatif Berbasis Manajemen Pemasaran Digital bagi UMKM Di Wilayah Rawamangun
}

\author{
${ }^{1}$ Muhammad Ramaditya, ${ }^{2}$ Syahrul Effendi, \\ ${ }^{3}$ Faris Faruqi, ${ }^{4}$ Arya Darmawan \\ ${ }^{1,2,3,4}$ Sekolah Tinggi Ilmu Ekonomi Indonesia Jakarta, 13320 \\ Author E-mail: ramaditya@stei.ac.id
}

\begin{abstract}
A B S T R A K
Usaha mikro, kecil dan menengah telah menjadi salah satu tulang punggung perekonomian Indonesia dan ASEAN. Presiden Jokowi Widodo memiliki harapan bahwa para pelaku bisnis usaha kecil ini dapat menjadi tumpuan utama dalam membangun keberlangsungan dan kemajuan bisnis di Indonesia. Dalam kondisi saat ini pemanfaatan sarana teknologi, informasi dan komunikasi dalam melakukan perdagangan secara elektronik adalah keharusan yang dilakukan oleh para pengusaha mikro, kecil dan menengah (UMKM) dalam upaya meningkatkan omset penjualan dan memberikan nilai lebih kepada konsumen. Kegiatan pengabdian masyarakat bertujuan untuk merubah para pelaku UMKM disekitar wilayah Rawamangun untuk menjadi seorang wirausaha kreatif yang memiliki nilai ekonomis tinggi serta bisnis yang memiliki keberlanjutan dalam meningkatkan keterampilan dan pengetahuan yang secara mendalam mengenai pemanfaatan teknologi informasi, lebih khususnya pada perdagangan elektronik. Metode yang digunakan pada pelatihan ini berupa ceramah, praktik, tanya-jawab dan studi kasus dengan menjelaskan konsep dan strategi pemasaran digital, serta coaching yang efektif serta mendapatkan umpan balik dari para peserta. Kegiatan ini juga memberikan manfaat berkelanjutan bagi peserta dalam pengarahan dan konsultasi bisnis secara intensif dalam menjalankan usaha mikro berbasis online demi meningkatkan potensi kerjasama yang luas untuk membangun ekonomi rakyat.
\end{abstract}

Kata Kunci: Perdagangan Elektronik, UMKM, Pemasaran, Keberlangsungan.

\section{A B S T R A C T}

Small medium enterprises (SME's) have become the backbone of the economies of Indonesia and ASEAN. President Jokowi Widodo has hopes that these small business entrepreneurs can become the main foundation in building business sustainability in Indonesia. Currently, the use of technology, information and communication facilities in e-commerce is a must need to do by SME's as an effort to increase sales turnover and provide more value to consumers. This community service activities aim to transform SME's around Rawamangun area into creative entrepreneur that have high value of economic and business sustainability in order to improve skills and knowledge in depth regarding the use of information technology, especially through e-commerce. The method used in this training is in the form of lectures, practices, questions and answers and case studies by explaining digital marketing concepts and strategies, as well as effective coaching and getting feedback from the participants. These activities also provide ongoing benefits for participants in business direction and consultation intensively in running online based micro business in order to increase the potential for cooperation to build the people's economy.

Keywords: e-Commerce, SME's, Marketing, Sustainability. 
Copyright (c) 2020 Authors. This is an open access article distributed under the Creative Commons Attribution License, which permits unrestricted use, distribution, and reproduction in any medium, provided the original work is properly cited.

\section{PENDAHULUAN}

Usaha mikro, kecil dan menengah (UMKM) telah menjadi salah satu tumpuan perekeonomian Indonesia. Dinamika bisnis ini sudah menmiliki proporsi sebesar 56,54 juta unit dari total keseluruhan pelaku usaha di Indonesia. Maka dari itu, beberapa kegiatan penguatan dan pengembangan bagi ketahanan pelaku UMKM perlu diutamakan. Trend perkembangan potensi bisnis ini di Indonesia juga mendapat dukungan pemerintah pusat dan perbankan dalam memberikan kredit untuk bisa bertahan pada kondisi ekonomi saat ini. Disamping itu, penggunaan teknologi informasi khususnya internet sudah menjadi bagian utama dari sebuah strategi pemasaran segala macam bentuk bisnis di dunia saat ini. Tanpa dukungan internet, sebuah UMKM hanya bisa merengkuh pasar lokal yang sempit, sementara persaingan UMKM yang semakin banyak bermunculan menyebabkan mau tidak mau UMKM harus melirik pasar yang lebih luas lagi yaitu pasar global dan mengupayakan untuk dapat meraihnya, dan salah satu cara adalah memanfaatkan kekuatan daya jangkau yang luas dari teknologi informasi komunikasi (TIK).

Potensi dan kesempatan para pelaku usaha kecil untuk menjadi seorang wirausaha (entrepreneur) yang kreatif sangat terbuka lebar. Seorang wirausaha adalah seorang yang dapat menciptakan kekayaan melalui inovasi, pusat pertumbuhan pekerjaan dan ekonomi, dan pembagian kekayaan yang bergantung pada kerja keras dan pengambilan risiko (Belch, 2004). Peningkatan julmah wirausaha menyebabkan peningkatan pertumbuhan ekonomi suatu negara dimana sangat erat kaitannya dengan para pelaku usaha mikro, kecil dan menengah. Sehingga apabila para pelaku UMKM dapat dibina dengan maksimal akan dapat melatarbelakangi gagasan oleh Schumpeter (1950) yaitu:

a. Menjadi seorang wirausaha yang mengenalkan produk baru dan mutu baru dari suatu produk. b. Wirausaha dapat mengenalkan metode baru berproduksi yang lebih komersial baik berdasarkan pengalaman maupun hasulkajian ilmiah dari suatu penelitian.

c. Wirausaha yang membuka pasar baru, baik dalam negeri ataupun di negara yang sebelumnya.

d. Wirausaha yang menggali sumber pasokan bahan baku baru bagi industry setengah jadi atau industry akhir.

e. Wirausaha yang menjalankan organisasi baru dari berbagai macam industry.

Kelima hal ini yang dapat mendorong peningkatan pertumbuhan ekonomi Indonesia melalui peningkatan produktivitias.

Dari sudut pandang ini, merubah kondisi dari pelaku UMKM menjadi seorang wirausaha yang dapat bertindak sebagai agen perubahan, membawa ide-ide baru bagi pasar, dan merangsang pertumbuhan melalui proses persaingan bisnis dapat menciptakan perubahan yang cukup besar bagi pertumbuhan ekonomi. Berkaitan dengan kewirausahaan, Schumpeter (1950) juga menekankan komponen kreatif. Kreativitas dalam kewirausahaan terletak pada kemampuan melihat peluang ekonomi yang baru. Dengan demikian beberapa pandangan mengenai kewirausahaan yang kreatif erat kaitannya dengan pergeseran dari era pertanian ke era industrialisasi lalu ke era informasi yang disertai dengan banyaknya penemuan di bidang teknologi informasi dan komunikasi (TIK) serta globalisasi ekonomi. Perkembangan industrialisasi menciptakan pola kerja, pola produksi dan pola distribusi yang lebih murah dan efisien dengan memasimalkan peran perdagangan elektronik.

Problematika usaha mikro, kecil dan menengah menyangkut sejumlah persoalan, seperti ketimpangan sturktural dalam alokasi dari penguasaan sumber daya, kinerja yang relatif keterbatasan pada permodalan, sumber daya manusia dan akses terhadap kelembagaan 
keuangan, teknologi, manajemen, pemasaran dan informasi (Kotler \& Gary, 2008). Perkembangan teknologi informasi komunikasi dan penerapannya di Indonesia yang semakin pesat, dengan pengguna internet di Indonesia yang diperkirakan mencapai 62 juta orang berdasarkan data Internet World Stats, hingga akhir 2017. Menjadikan perhatian UMKM untuk segera bertindak untuk mengenal, memahami dan menggunakan teknologi tersebut dalam kegiatan bisnisnya. Ditambah lagi dengan semakin murahnya tarif dan perangkat koneksi internet seperti modem dan laptop dewasa ini, dan kehadiran perangkat tablet PC yang semakin popular saat ini. Serta populernya teknologi informasi digunakan sebagai media transaksi belanja seperti $e$-ticketing dan $e$-banking .

Namun demikian potensi pasar yang cukup besar tersebut ternyata tidak berbanding lurus dengan fakta kinerja positif UMKM. Banyak para pelaku UMKM saat ini tidak dapat berkembang disebabkan sulitnya menaklukkan pangsa pasar karena keterbelakangan teknologi dan modal usaha yang terbatas. Bagi UMKM yang ingin terjun memanfaatkan TIK, dihadapkan pada kendala tersendiri, karena diperlukan biaya pengembangan dan sumber daya manusia yang cukup besar, sehingga hanya pengusaha dengan modal besar saja yang dapat menerapkan TIK dalam aktivitas bisnisnya (Fill \& Graham, 2005). Kondisi ini menyebabkan semakin tersingkirnya peran UMKM dalam merebut pangsa pasar global dibanding pengusaha bermodal besar. Namun demikian ditengah pesatnya pertumbuhan aplikasi teknologi informasi berbasis internet di dunia, UMKM memiliki alternatif media transaksi bisnis online berbasis internet yang tersebar secara gratis. Diantaranya seperti Bukalapak dan lain sebagainya. Yang semuanya itu bisa dimanfaatkan sebagai media transaksi bisnis online alternatif yang murah dan juga justru lebih efektif karena telah memiliki banyak pelanggan yang bisa menjadi target pasar kita dan siap menunggu produk-produk yang ditawarkan oleh UMKM.

Namun demikian dalam perjalananya ternyata banyak pelaku bisnis UMKM yang tidak atau belum menerapkan toko online alternatif yang banyak tersedia gratis di internet tersebut. Hal ini disebabkan oleh banyak faktor diantaranya ketidakpercayaan pada transaksi online yang disediakan oleh internet. Juga persepsi yang menganggap bahwa banyaknya peluang terjadinya penipuan dan manipulasi dalam transaksi online, dan lain sebagainya. Namun demikian dari beberapa yang telah menggunakan platform online tidak semuanya menunjukkan kinerja bisnis yang baik. Oleh karena itu UMKM perlu untuk memahami konsep bisnis online, media pendukungnya, dan karakteristiknya sehingga pengambilan keputusan terkait dapat terealisasi denganbaik. Begitu juga diperlukan pemahaman transaksi online di internet untuk dimanfaatkan secara maksimal agar didapat dampak positif yang signifikan.

Berdasarkan beberapa fakta tersebut diatas dan berdasarkan beberapa hasil pengamatan kami yang tertuang dalam beberapa karya ilmiah dan laporan pengabdian masyarakat yang telah kami lakukan maka kami merasa perlu untuk melakukan kegiatan lanjutan dalam mendukung dan membantu para pelaku UMKM untuk dapat memahami dan memanfaatkan teknologi digital sebagai media transaksi bisnis mereka dalam menembus pasar lokal maupun internasional, khususnya terkait dengan upaya menyiapkan toko online yang baik untuk di promosikan secara online sehingga bisnis online tersebut dapat membawa dampak penjualan yang baik bagi bisnis UMKM. Pelatihan ini menjadi bentuk pelatihan yang lebih mendalam untuk menjawab dan menemukan kemungkinan problem yang akan dihadapi UMKM dalam menerapkan menjalakan bisnis secara online. Pelatihan ini memiliki tujuan untuk meningkatkan kemampuan UMKM untuk menjadi seorang wirausaha yang kreatif dalam memanfaatkan teknologi informasi untuk mengkomunikasi produk mereka secara efisien dan efektif. Luaran dari pelatihan ini diharapkan UMKM dapat mengenal dan memahami bagaimana pemasaran secara online lebih dalam, sehingga dapat dipastikan UMKM bisa meningkatkan omset jualan dan memberikan nilai tambah produk kepada konsumen. 


\section{METODE PELAKSANAAN}

Pelatihan ini mensinergikan beberapa aktivitas dalam pengembangan kewirausahaan yang kreatif yaitu dengan harmonisasi antara bisnis, cendekiawan dengan pemerintah yang dapat menjadi sebuah energi besar dalam akselerasi pengembangan ekonoomi di Indonesia. Beberapa faktor-faktor yang mendorong perkembangan kewirausahaan kreatif di Indonesia (Kemdag RI 2008) adalah:

a. Dari sisi pemerintah: arahan edukatif, penghargaan insan kreatif, konservasi dan insentif.

b. Dari sisi bisnis: kewirausahaan, business coaching dan mentoring, skema pembiayaan, pemasaran dan business matching, serta komunitas kreatif.

c. Dari sisi cendekiawan: kurikulum berorientasi kewirausahaan kreatif, riset inovatif multidisiplin, Lembaga Pendidikan dan pelatihan.

Dalam kegiatan ini, metode yang dilakukan adalah berbentuk pelatihan atau pelatihan yang dilakukan dalam format pelatihan di labolatorium komputer dan sesi praktikal dimana materi disampaikan secara teoritis terkai t konsep perdagangan elektronik dan komunikasi pemasaran, perkembangan bisnis online, konsep bisnis pada perdagangan elektronik, kendala dan hambatan yang dihadapi dalam bisnis online. Kemudian materi dipraktikan melalui tutorial dan diupayakan dengan target menghasilkan penjualan online di beberapa platform perdagangan elektronik yang tersedia di Indonesia. Adapun materi yang akan diberikan meliputi konsep dan perkembangan perdagangan elektronik, implementasi dan praktik menggunakan perdagangan elektronik, dan teknik update, modifikasi serta pengisian konten produk di perdagangan elektronik.

Peserta pelatihan adalah para UMKM di sekitar wilayah Rawamangun yang telah memiliki akun email dan menggunakan perdagangan elektronik yang berjumlah 47 orang. Metode yang digunakan pada pelatihan ini berupa ceramah, praktik, tanya-jawab dan studi kasus dengan menjelaskan konsep dan strategi pemasaran digital, serta coaching yang efektif serta mendapatkan umpan balik dari para peserta. Alat peraga yang digunakan adalah perangkat komputer, jaringan internet, contoh produk yang dibawa masingmasing peserta UMKM yang terdiri dari berbagai latar belakang usaha seperti usaha kuliner, usaha bidang fashion, bidang Pendidikan, bidang agrobisnis, bidang kerajinan tangan, bidang otomotif serta usaha elektronik dan gadget. Para pelaku usaha diminta untuk mempersiapkan produk yang dimiliki untuk dapat langsung dipraktikan dan melakukan diskusi jika ditemukan terdapat permasalahan didalam usaha yang mereka jalankan. Pada saat pelatihan berlangsung para pelaku UMKM diberikan materi mengenai kebijakan pengembangan produk, strategi harga, dan pengenalan beberapa aplikasi perdagangan elektronik. Disamping, itu para peserta diberikan soal latihan dan studi kasus berkaitan pemasaran produk melalui online, pengetahuan produk, teknik dasar foto produk, tatacara penulisan dan strategi pengembangan produk melalui perdagangan elektronik.

\section{HASIL DAN PEMBAHASAN}

Kegiatan pelatihan kewirausahaan dan strategi pemasaran digital ini dilaksanakan pada tanggal 04 Juli 2019 bertempat di ruang simulator bisnis Sekolah Tinggi Ilmu Ekonomi Indonesia Jakarta dengan melaksanakan pelatihan pemasaran secara digital secara mendalam dan dibagi menjadi empat sesi sebagai berikut:

1. Sesi pertama: Penjelasan secara komprehensif mengenai konsep perdagangan elektronik dan komunikasi pemasaran, perkembangan bisnis online, konsep bisnis pada perdagangan elektronik, kendala dan hambatan yang dihadapi dalam bisnis online. Pada sesi ini, para peserta diberikan pembekalan dan penyegaran materi untuk mengetahui perkembangan bisnis online secara luas dari berbagai negara. Sebagai tambahan diberikan stimulus kepercayaan diri melalui audio dan video untuk memperlihatkan cerita sukses 
dari sebagaian pelaku UMKM yang lebih dahulu memaksimalkan peran teknologi pada era Industri 4.0 saat ini.

2. Sesi kedua: Mempraktikan materi melalui tutorial dan berupaya untuk dapat memiliki akun dan mencoba berjualan melalui perdagangan elektronik di beberapa pasar online yang sudah tersedia. Hal ini dilakukan dikarenakan setiap platform digital yang tersedia seperti bukalapak, Tokopedia, shoppe, blibli dan sebagainya memiliki karakteristik dan keunggulan tersendiri dalam memberikan kemudahan didalam melakukan transaksi jual beli melalui online. Sehingga dalam hal ini para pelaku UMKM dapat memahami perilaku konsumen di media online dan menentukan cara yang terbaik dalam memasarkan produknya.

3. Sesi ketiga: Para peserta juga diberikan contoh soal dan studi kasus berkaitan dengan pemasaran produk melalui online, pengetahuan produk, teknik dasar foto produk, penulisan, dan strategi pengembangan produk melalui perdagangan elektronik. Sesi ini bertujuan untuk mengetahui sejauh mana pemahaman para peserta mengenai dinamika penjualan online, sehingga akan ditemukan peluang untuk melakukan perbaikan bagi masing-masing peserta agar dapat meningkatkan kinerja pemasarannya melalui peran digital. Pada kegiatan ini juga dilakukan penekanan dalam hal mengidentifikasi peluang. Suatu peluang dikatakan potensial untuk dimanfaatkan jika memenuhi kejelasan bentuk dan besarannya, mempunyai nilai ekonommis yang menguntungkan dan didukung oleh kemampuan para pelaku usaha dalam memanfaatkannya. Beberapa hal penting dalam mengidentifikasi peluang pengembangan produk yaitu dengan:

a. Mencatat setiap perkembangan dalam lingkungan bisnis.

b. merenungkan dan mencari celah-celah yang dapat dimanfaatkan dari setiap perkembangan yang ada.

c. mencatat dengan baik setiap peluang yang ditangkap.

d. membuat rencana secara kasar dan cepat tentang Langkah selanjutnya.

e. melakukan penilaian secara cepat apakah peluang tersebut secara potensial mampu digarap.

4. Sesi keempat: Diskusi dan tanya jawab yang dilakukan oleh para narasumber yaitu para dosen Sekolah Tinggi Ilmu Ekonomi Indonesia yang dapat memberikan solusi atas masalahmasalah yang terjadi di lapangan, serta memberikan strategi-strategi pemasaran yang tepat agar kelangsungan bisnis para pelaku UMKM mendapatkan keberlanjutan dan bersaing pada era disrupsi saat ini. Beberapa hal yang ditekankan dalam proses mengelola informasi dengan melakukan penilaian secara cepat dan diperkirakan memanfaatkan peluang tersebut. Maka tahap selanjutnya melakukan pencarian dan pengolahakn informasi seara rinci dan teknis. Penguasaan informasi tersebut sangat menguntungkan apabila didukung dengan perencanaan yang matang dan mengetahui sumber-sumber risiko dan kendala yang dapat didentifiksai secara dini, sehingga diketahui cara mengatasinya.

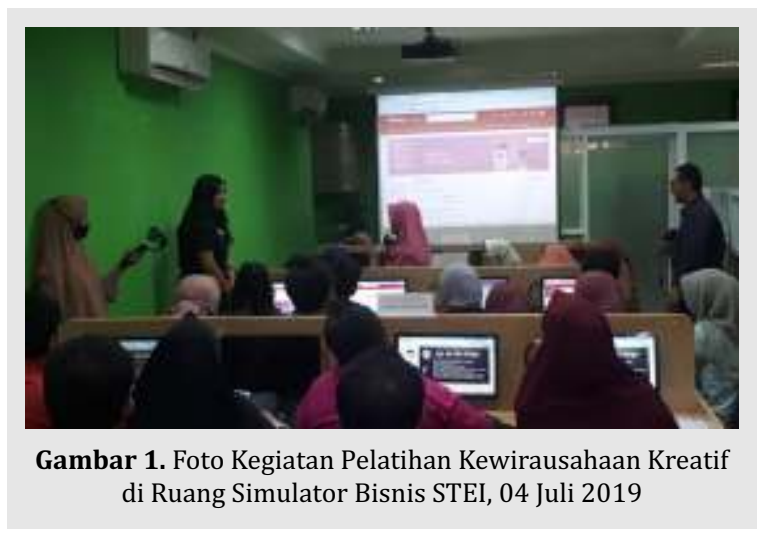

Sebagaimana halnya kewirausahaan pada umumnya, dalam berupaya menjadi seorang kewirausahaan kreatif ditemukan juga kendala, seperti risiko, modal, lingkungan, sosial, sistem pasar dalam negeri dan mutu pengelolaan. Kendala tersebut dapat menyebabkan terjadinya kegagalan bila tidak diantisipasi dengan suatu perencanaan dan pemanfaatan teknologi informasi. Pemilik yang sekaligus menjadi pengelola UMKM 
bertanggung jawab dalam mengembangkan teknologi informasi dalam memasarkan produk mereka sehingga dapat memberikan nilai tambah bagi konsumen serta menjadi pengawas dalam kegiatan produksi yang dimulai dari tahap pengadaan bahan baku sampai dengan pemasaran ke konsumen.

Pengelolaan perdagangan elektronik harus juga mampu untuk mengefisiensikan alokasi sumber daya teknologi (metode, Teknik dan prosedur) yang ada dengan baik dan benar. Beberapa penekanan pada kegiatan pelatihan kewirausahaan kreatif UMKM ini ditekankan dalam upaya pengambilan keputusan, yang meliputi identifikasi masalah, mengikhtisarkan fakta-fakta, mendata dan menganalisis alternatif strategi pemasaran, serta mengambil tindakan dalam pengendalian terhadap aspek-aspek bisnis, seperti pemasaran, program pengembangan usaha seperti tinjauan ulang sasaran dan tujuan, analisis situasi saat ini yang terkait dengan tujuan dan proyeksi penghasilan. Adapun hasil kegiatan yang telah dilaksanakan sesuai dengan rancangan atau rencana kegiatan adalah sebagai berikut:

a. Peningkatan jiwa kewirausahaan dan keterampilan teknis dari sisi pemasaran: pada kegiatan ini, peserta UMKM dapat bertransformasi menjadi seorang wirausahawan baru berbasis kreatifitas yang memiliki kompetensi (knowledge, skill, ability, attitude dan b ehavior) yang mnjeadikan suuatu moment of choice yang sangat bermanfaat bagi percepatan pertumbuhan ekonomi wilayah dan menjawab tantangan dalam memasuki era globalisasi memlaui proses belajar berkesinambungan, yang didukung oleh penguasaan iptek, serta sikap piker yang posiitif, kritis, kreatif dan inovatif.

b. Peningkatan dan penguasaan teknologi informasi dalam memasarkan produk: para peserta pelatihan ini mendapatkan pemahaman tentang mekanisme pasar dan kemampuan bersaing yang didasarkan pada orientasi bagaimana harus mengerjakan sesuatu (how things ought to be done) dan bagaimana sesuatu dikerjakan (how things are done), maka diperlukan informasi melalui database online dan perdagangan elektronik dalam mengetahui pasar aktual, pesaing utama, faktor yang mempengaruhi kesuksesan dan kegagalam produk dalam pasar online dan pemahaman kebutuhan konsumen) dan operasional pemanfaatan peluang bisnis skala usaha didukung oleh strategi teknologi dan pasar.

c. Peningkatan akses dan memperbesar pasar yang didukung oleh strategi pemasaran dan informasi pasar: Keberhasilan pemilihan platform perdagangan online yang tepat dapat mempercepat pertumbuhan UMKM (Produk, proses dan kepuasan konsumen) sebagai dampak kompetisi teknologi dan taraf control teknologi serta konsolidasi ase (kemampuan memasarkan dan mengembangkan). Untuk itu, selanjutnya diperlukan tahapan pengidentifikasian pengalaman, penemuan pola, perencanaan dan peningkatan lebih lanjut dari beberapa target yang telah di siapkan oleh para peserta.

d. Peningkatan hubungan kemitraan baik sesama UMKM, dan terkait dengan aspek promosi dan informasi dengan pihak lain: Meningkatkan hubungan kemitraan dengan pemantapan kemitraan dengan sesame pengusaha kecil yang hadir, pemantapan kemitraan dengan beberapa peserta membuat Kerjasama baru dalam hal promosi, modal, informasi dan lainlain.

\section{KESIMPULAN DAN SARAN}

Membina para pelaku usaha mikro, kecil dan menengah pada ruang simulator bisnis STEI dapat menumbuhkan dan mengembangkan jaringan kerja antara unusr perguruan tinggi dan dunia usaha dalam memberikan bantuan teknik dan konsultasi manajemen pemasaran dalam rangka meningkatkan kemampuan dan keterampilan manajerian dan entrepreneurial. Disamping itu aktivitas ini dapat membentuk jaringan kerja antara lembaga pendidikan dan pelaku usaha 
dalam rangka meningkatkan peluang bisnis sserta memanfaatkan fasilitas ruang simulator bisnis sebagai wahana pengembangan proses, pengelolaan dan pemasaran bernilai tambah tinggi. Disamping itu, tim pengabdian masyarakat ini juga melakukan pelayanan konsultasi dan kesinambungan kepada para peserta UMKM yang disesuaikan dengan tahap perkembangannya, sehingga memudahkan peningkatan proses pembelajaran pemasaran digital ke tahap berikutnya.

Program ini bersinergi dengan program pemerintah untuk meningkatkan daya saing bangsa dan negara yang ditunjukkan oleh kemampuan perekonomian dalam menghasilkan barang dan jasa melalui online, disamping agar mampu bersaing di pasar dalam maupun luar negeri. Untuk itu, agar proses kemajuan tersebut dapat diraih secara maksimal, maka perlu diciptakan kesempatan bagi semua jenis kegiatan dan skala usaha dari para pelakunya, diantaranya pemberdayaan UMKM dan pembentukan wirausahawan kreatif dalam meningkatkan produktivitas usahanya bagi pertumbuhan ekonomi atau pembentukan modal yang memberi manfaat bagi orang banyak. Sehingga dapat memanfaatkan potensi yang dimiliki oleh masingmasing UMKM untuk menuju menjadi wirausaha professional, maju, memiliki pengetahuan yang baik dalam menjelankan usaha, serta mempunyai rencana dalam pengembangan usaha yang jelas untuk masa depan.

\section{DAFTAR PUSTAKA}

Belch, George E., \& Belch, M, A. (2004). Advertising and Promotion: An Integrated Marketing Communication Perspective. New York. McGraw Hill.

Fill, C., \& Graham H. (2005). Marketing Communication. Elsevier. Butterworth Heinemann.

Kotler, P., \& Gary A. (2008). Principles of Marketing, $12^{\text {th }}$ Edition, Pearson Prentice Hall.

Lee, J., \& J. Runge. (2001). Adoption of Information Technology in Small Business: Testing Drivers of Adoption for Entrepreneurs. Journal of Computer Information System, Fall, 42,1.

Raymond, M., \& George P.S. (2004). Management Information Systems, Ninth Edition, Prentice Hall. 